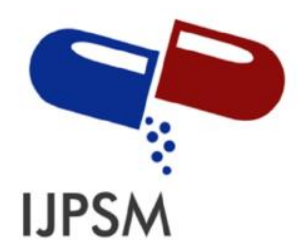

Engla Kartika et al, Int. Journal of Pharmaceutical Sciences and Medicine (IJPSM),

Vol.6 Issue. 1, January- 2021, pg. 75-82

ISSN: 2519-9889

Impact Factor: 3.426

\title{
Phytochemical and Pharmacological Review of Carrot (Daucus carota L.)
}

\author{
Engla Kartika $^{1}$; Zulharmita ${ }^{1}$; Boy Chandra ${ }^{1}$; Harrizul Rivai ${ }^{2 *}$ \\ ${ }^{1}$ College of Pharmacy (STIFARM), Jl. Raya Siteba Kurao Pagang, Padang 25147, Indonesia \\ ${ }^{2}$ Faculty of Pharmacy, Andalas University, Limau Manih Campus, Padang 25163, Indonesia \\ "Email: harrizul@yahoo.co.id and harrizul@phar.unand.ac.id
}

DOI: 10.47760/ijpsm.2021.v06i01.006

\begin{abstract}
Carrots (Daucus carota L.) are vegetables that are widely recognized by Indonesians. This plant is easy to obtain and has excellent benefits and benefits. Therefore, it is necessary to get information about phytochemicals and their pharmacological effects. Information search is carried out through Google Scholar. The results show that carrots are rich in chemical compounds such as vitamins (A, B, C), alkaloids, carotenoids, flavonoids, tannins, anthraquinones, carbohydrates, saponins, diterpenes, steroids, phenolic acids, beta-carotene, phenols, coumarin, triterpenoids, essential oils. Chlorogenic acid, folic acid, pantothenic acid, and minerals (sodium, calcium, phosphorus, iron, potassium, sodium, magnesium). These compounds have been isolated from the leaves, tubers, bark, and flowers by various extraction methods. Pharmacologically, this plant has been reported to have antioxidant, antibacterial, sedative, anti-inflammatory, antifungal, anthelmintic, anticancer, antidepressant, anti-cholesterol, gastric anti-ulcer, and renal protective activity. Thus, carrots can be used as ingredients for herbs, and further research needs to be done to isolate medicinal compounds from carrots.
\end{abstract}

Keywords: Carrots, Daucus carota L., Phytochemicals, Pharmacological Activities

\section{Introduction}

Carrots (Daucus carota L.) are herbaceous plants of the Apiaceae family [1]. Carrots are biennial plants (life cycle 12-24 months) that store large amounts of carbohydrates for themselves [2]. Carrot plant morphology grows up to 30-100 cm or more, comes from areas with a temperate climate (subtropical). Carrots consist of leaves, flowers, tubers, and roots. Carrot leaves are double or triple pinnate compound, and leaflets are lanceolate (stripes). It has 5-7 petiole, stiff and thick petiole with a smooth surface. At the same time, the leaves are limp and thin.

The stems of the carrot plant are so short they are barely visible. The trunk is also round, not woody, a little stiff, and small in diameter, dark green. It has no branches but is overgrown by longleaf stalks so that it looks branched. Carrot plants have taproots. The taproot will change its form and function to become a storage area for food reserves. Roots will turn out to be large and round lengthwise, up to $6 \mathrm{~cm}$ in diameter and up to $30 \mathrm{~cm}$ long, depending on the variety. Carrot plant flowers grow on the tip of the plant and are white. Flowers have short, thick stalks. The flowers lie in the same plane. Carrot flowers that have been pollinated will produce fruit and seeds that are small and hairy. Carrot tubers have a reddish yellow, white, yellow, and purple color. But in Indonesia, which is mostly found, it is reddish yellow. Taproot that has changed shape is often called or known as carrot tubers [3]. Carrot plant morphology is shown in Figure 1 [4]. 


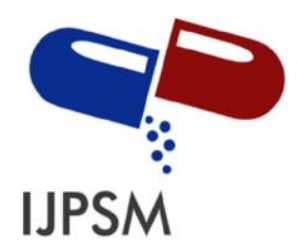

Engla Kartika et al, Int. Journal of Pharmaceutical Sciences and Medicine (IJPSM), Vol.6 Issue. 1, January- 2021, pg. 75-82

ISSN: 2519-9889

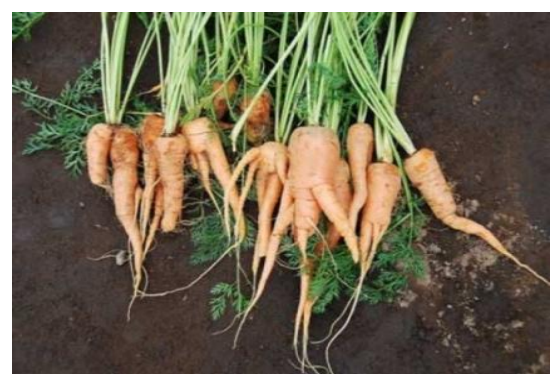

Impact Factor: 3.426
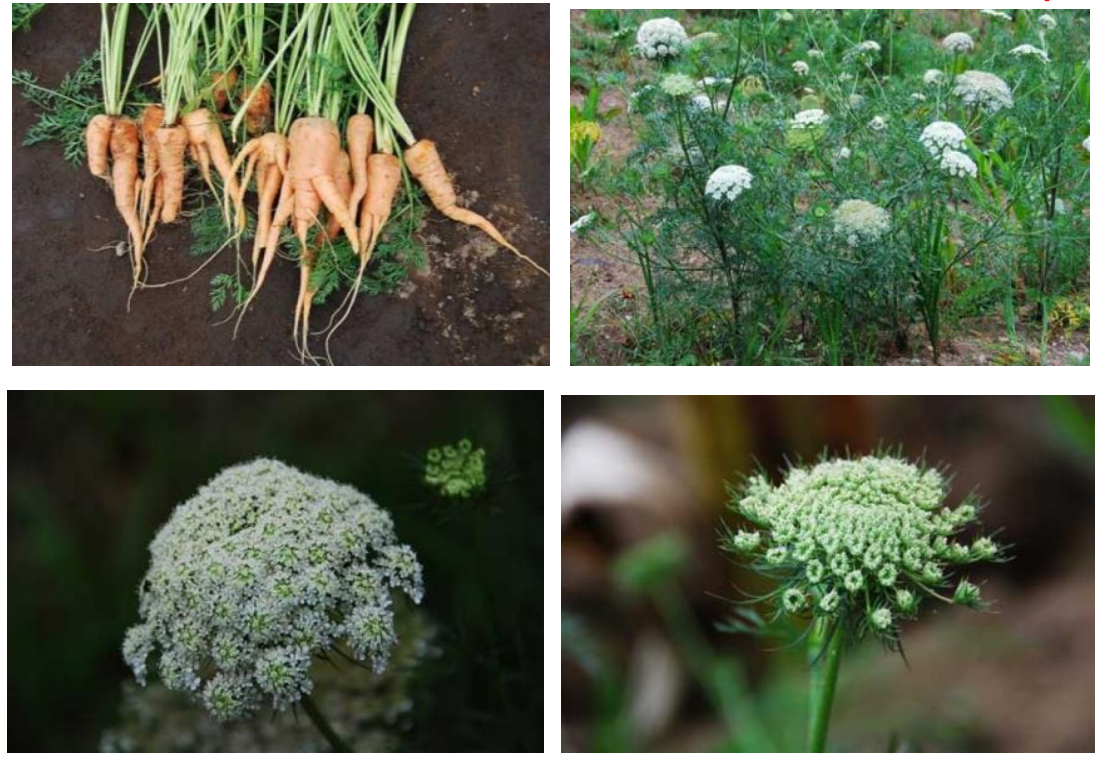

Figure 1: Morphology of Carrot (Daucus carota L.) Plants [4]

Carrot plants (Daucus carota L.) can be classified as follows: [4]

Kingdom: Plantae

Subkingdom: Tracheophyta

Superdivision: Spermatophyta

Division: Magnoliophyta

Class: Magnoliopsida

Order: Apiales

Family: Apiaceae

Genus: Daucus

Species: Daucus carota L.

Other names: [5]

a. Synonym: Daucus sativus

b. Region name: boktel (Sundanese), wortel (Javanese), and ortel (Madura)

c. Foreign name: Carrot, wild carrot fruit

d. Simplicia name: Carotae Rhizoma (carrot tuber)

\section{Data Collection}

This review article's preparation uses literature study by looking for references that are relevant to the cases or problems found. Reports have been collected from national and international journals in the past 20 years (2000-2020) and using official books. The data search in this review article uses online media through trusted sites such as Google Scholar, Science Direct, Pubmed, and Pubchem using the search keywords Daucus carota L, phytochemical and pharmacological activities.

\section{Phytochemical Review}

Phytochemical screening of carrot tuber extract using ethyl acetate and methanol showed the presence of steroids / triterpenes, saponins, flavonoids, and tannins. The results of the nutrient analysis of the tuber extract showed that the content of protein $(14.59 \%)$, lipids $(10.3 \%)$, fiber $(9.07 \%)$, carbohydrates $(51.81 \%)$, moisture 


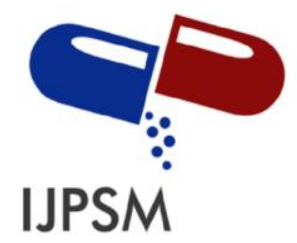

Engla Kartika et al, Int. Journal of Pharmaceutical Sciences and Medicine (IJPSM), Vol.6 Issue. 1, January- 2021, pg. 75-82

ISSN: 2519-9889

Impact Factor: 3.426

$(10.23 \%)$ and high levels of ash $(12.99 \%)$ and rich in elements $\mathrm{P}(11 \mathrm{mg} / \mathrm{L}), \mathrm{Na}(5.38 \mathrm{mg} / \mathrm{L}), \mathrm{Fe}(3.19 \mathrm{mg} / \mathrm{L})$, $\mathrm{K}(2.25 \mathrm{mg} / \mathrm{L}), \mathrm{Ca}(2.02 \mathrm{mg} / \mathrm{L}), \mathrm{Mn}(1.15 \mathrm{mg} / \mathrm{L}), \mathrm{Mg}(1.02 \mathrm{mg} / \mathrm{L}), \mathrm{As}(0.83 \mathrm{mg} / \mathrm{L}), \mathrm{Se}(0.40 \mathrm{mg} / \mathrm{L}), \mathrm{Zn}(0.26$ $\mathrm{mg} / \mathrm{L}), \mathrm{Cu}(0.13 \mathrm{mg} / \mathrm{L}), \mathrm{Cr}(0.02 \mathrm{mg} / \mathrm{L}), \mathrm{Ni}(0.17 \mathrm{mg} / \mathrm{L})$, and $\mathrm{Pb}(0.04 \mathrm{mg} / \mathrm{L})$ [ 6].

Methanol and acetone extracts obtained from carrot peels (Daucus carota L.) contained diterpenes, steroids, flavonoids, and phenolic acids [7]. Meanwhile, in the ethanol extract of carrot root (Daucus carota L.), alkaloids, flavonoids, tannins, carbohydrates, phenols, coumarin, terpenoids, and chlorogenic acid were found $[2,8]$.

The essential oil of the flower and root (Daucus carota L.) was obtained by hydrodistillation and analyzed by a combination of $\mathrm{GC}, \mathrm{GC} / \mathrm{MS}$, and ${ }^{13} \mathrm{C}-\mathrm{NMR}$. Analysis of flower oil identified 32 components (19 monoterpenes, four sesquiterpenes, two phenylpropanoids, and seven non-terpenic acyclic aldehydes and alcohols). The essential oils of flowers consist of hydrocarbon monoterpenes $(68.4 \%)$ and sabinene $(51.6 \%), \alpha-$ pinen $(2.1 \%), \beta$-pinen $(2.3 \%), \gamma$-terpinen $(3 \%), \rho$-cymen $(4.2 \%)$. Oxygenated monoterpenes are mostly represented by terpinene-4-ol (11.0\%). The sesquiterpene fraction, which constituted $4.8 \%$, consisted mostly of the bicyclic alcohol eudesm-6-3n-4-ol (3.6\%). Six components of root oil were identified as being rich in phenylpropanoid $(76.3 \%)$, consisting of two main components, namely dilapiole $(46.6 \%)$ and myristicin (29.7\%). The relatively low levels of monoterpene are hydrocarbons $(7 \%)$, limonene $(3.6 \%), \rho$-cymen $(1.5 \%)$, $\alpha$-phellandrene (1\%), and myrcene $(0.9 \%)$ [9].

The chemical composition analysis of the ethanol extract (leaves \& seeds) of Algerian wild carrots using the GC and GC-MS methods showed 47 of the 48 total components of carrot leaf and essential seed oil. The main component of essential leaf oil was $\alpha$-pinen $(27.44 \%)$, sabinen $(25.34 \%)$, germacrene $(16.33 \%)$. The main components of carrot seed essential oil are geranyl acetate $(52.45 \%)$, Cedrone $(14.04 \%)$, Nazarene $(11.39 \%)$. The total phenol content of leaf extract (13.83 mgGAE/g) and seed extract (7.08 $\mathrm{mgGAE} / \mathrm{g}$ ) [10].

Ethanol extracts from various carrot varieties where the total polyphenol content analyzed using FolinCiocalteu reagent $(F C R)$ ranged from $81.25 \pm 13.11 \mathrm{mg} / \mathrm{kg}$ to $113.69 \pm 11.57 \mathrm{mg} / \mathrm{kg}$. Beta carotene content ranged from $24.58 \pm 2.38 \mathrm{mg} / \mathrm{kg}$ to $124.28 \pm 3.54 \mathrm{mg} / \mathrm{kg}$ and was analyzed by spectrophotometry at a wavelength of $450 \mathrm{~nm}$. Statistically, the highest value of total polyphenols was found in colosseum varieties $(113.69 \pm 11.57 \mathrm{mg} / \mathrm{kg})$. This variety also has the highest beta carotene content $(124.28 \pm 3.54 \mathrm{mg} / \mathrm{kg})$ and the highest antioxidant activity value $(9.83 \pm 0.62 \%)$ [11]

Quantitative analysis of beta carotene levels in raw carrots and boiled carrots extracted with hexane: acetone: ethanol (2: 1: 1) was analyzed using visible spectrophotometry. The results showed that the beta carotene content of raw carrots was $34.94 \pm 7.81 \%$, and that of boiled carrots was $23.31 \pm 4.246 \%$. Based on the paired t-test sample test shows that the P-value is $0.06(>0.05)$, which means that there is no difference between raw and boiled carrots [12].

\section{Pharmacological Review \\ 4.1 Antioxidant Activity}

The antioxidant activity of several varieties of carrot tubers (chantenay, imperator, and nantes) was tested using a variety of solvents (n-hexane, ethyl acetate, and methanol). The test was carried out using the DPPH method using a spectrophotometer at a wavelength of $517 \mathrm{~nm}$. Compounds that have the potential to act as antioxidants include flavonoids and alkaloids. The results of the antioxidant activity test showed that the extract from carrot tuber varieties had different antioxidants. In chantenay type carrots, the highest antioxidant was found in the nhexane extract with IC50 $108.437 \mu \mathrm{g} / \mathrm{mL}$. The highest imperator type carrot was in methanol extract with IC50 $229.811 \mu \mathrm{g} / \mathrm{mL}$. The highest antioxidant type was ethyl acetate extract with IC50 160.083 $\mu \mathrm{g} / \mathrm{mL}$ [13].

Antioxidant testing of carrot tuber extract using the DPPH method used three types of solvents: n-hexane, ethyl acetate, and methanol. The test results showed that the EC50 value in the n-hexane extract was $490.74 \mu \mathrm{g} / \mathrm{mL}$, the EC50 ethyl extract was $86.29 \mu \mathrm{g} / \mathrm{mL}$, and the methanol extract was EC50 $166.79 \mu \mathrm{g} / \mathrm{mL}$. It can be concluded that ethyl acetate extract has the highest antioxidant properties [6].

The antioxidant activity of carrot oil extract using the 1,1-diphenyl-2-picril hydrazyl (DPPH) method, the ferrous ion chelating assay (FIC), and the iron-reducing antioxidant power (FRAP) test showed that carrot oil 


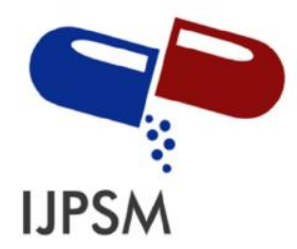

Engla Kartika et al, Int. Journal of Pharmaceutical Sciences and Medicine (IJPSM), Vol.6 Issue. 1, January- 2021, pg. 75-82

ISSN: 2519-9889

Impact Factor: 3.426

had antioxidant activity in all the tests used. The results showed that the FRAP value was $164 \pm 5.5 \mathrm{mmol}$ and the IC50 value for the DPPH test was $2.1 \pm 0.03 \mathrm{mg} / \mathrm{mL}$, and the FIC was $0.43 \pm 0.02 \mathrm{mg} / \mathrm{mL}$ [14].

\subsection{Anti-inflammatory Activity}

The ethanol extract of carrots (Daucus carota L.) gave an anti-inflammatory effect on the Wistar strain mice injected with carrageenan. The dose of $400 \mathrm{mg} / \mathrm{kg} \mathrm{BW}$ showed that carrot extract impacted inflammation by $46.6 \%$ [15].

The anti-inflammatory effect of carrot root extract has been tested on acetic acid-induced colitis in Wistar rats. The animals received pre-treatment for seven days with carrot extract (100, 200, and $400 \mathrm{mg} / \mathrm{kg}$, PO) before colitis induction. Colitis was induced by administering $2 \mathrm{~mL}(4 \% \mathrm{v} / \mathrm{v})$ acetic acid solution intrarectally, resulting in a significant reduction in animal body weight, food, and water intake. Carrot root extracts (200 and $400 \mathrm{mg} / \mathrm{kg}$, PO) significantly decreased stool consistency, macroscopic score, colonic weight, colonic width, weight-to-colonic length ratio, spleen weight, ulcer area, ulcer index, colonic myeloperoxidase (MPO), and nitric oxide. It significantly attenuates the histological changes associated with acetic acid-induced ulcerative colitis [16].

\subsection{Anthelmintic Activity}

The anthelmintic effect of ethanol extract of local and imported carrot tubers against Ascaris suum worms was carried out using six treatment groups, namely $0.9 \% \mathrm{NaCl}$ as a negative control, $0.25 \%$ pyrantel pamoate as a positive control, local and imported carrot extracts with a concentration of 10\%, $20 \%$, 40\%, and 60\%. The fastest time of death of Ascaris suum worms at a concentration of $60 \%$ of local varieties of carrots, which is 36 minutes, and imported carrots for 43 minutes. Types of compounds that can act as anthelmintics are quercitrin, flavonoids, saponins, and tannins. This study proved that the ethanol extract of local and imported varieties of carrots has an anthelmintic effect in ascariasis cases [17].

\subsection{Antifungal Activity}

The ethanol extract of carrot tuber (Daucus carota L.) has strong antifungal activity in inhibiting the growth of Candida albicans. There is an increase in the diameter of the inhibition zone at each increase in concentration, namely: $1 \% \mathrm{w} / \mathrm{v}(15.7 \mathrm{~mm}), 3 \% \mathrm{w} / \mathrm{v}(18.9 \mathrm{~mm}), 5 \% \mathrm{w} / \mathrm{v}(19.8 \mathrm{~mm})$ and very strong at positive control $(20.1$ $\mathrm{mm}$ ). The categories of inhibition zones according to Davis and Stout are as follows: Very strong (inhibition zone > $20 \mathrm{~mm}$ ), Strong (10-20 mm inhibition zone), Moderate (inhibition zone 5-10 mm), and Weak (inhibition zone $<5 \mathrm{~mm}$ ). It can be concluded that the greater the concentration of ethanol extract of carrot tubers (Daucus carota L.), the greater the resulting inhibition because the number of active components in it is also greater [18].

The antifungal activity test of carrot juice (Daucus carota L.) on Candida albicans fungus's growth in vitro was tested using five different concentrations. This test shows that carrot juice (Daucus carota L.) cannot inhibit growth at low concentrations of 5\%, 25\%, and 50\% but can inhibit fungal growth at high concentrations of $75 \%$ and $100 \%$ because high concentrations can provide a zone inhibition is greater than the lower concentration [19].

\subsection{Antibacterial Activity}

The test for the antibacterial activity of the ethanol extract of carrot tubers was analyzed using the One Way ANOVA method (one-way analysis of variance) followed by the Duncan test. The data results show that the extract concentrations of 5\%,10\%,20\%, 40\%, and $80 \%$ have provided activities that can inhibit the growth of the tested bacteria. There is an increase in the diameter of the inhibition zone at each increase in concentration of $5 \%(3.50 \mathrm{~mm}), 10 \%(3.67 \mathrm{~mm}), 20 \%(4.83 \mathrm{~mm}), 40 \%(5.16 \mathrm{~mm})$ and $80 \%(6,67 \mathrm{~mm})$ for Escherichia coli and a concentration of $5 \%(3.17 \mathrm{~mm}), 10 \%(3.83 \mathrm{~mm}), 20 \%(4.00 \mathrm{~mm}), 40 \%(4.17 \mathrm{~mm})$ and $80 \%(4,33 \mathrm{~mm})$ for Staphylococcus aureus bacteria. However, it is not effective in inhibiting bacterial activity because the two test bacteria's inhibition zone is moderate. Meanwhile, to inhibit must use a zone of inhibition that is strong (5$10 \mathrm{~mm}$ ) or strongest (> $20 \mathrm{~mm})[20]$. 


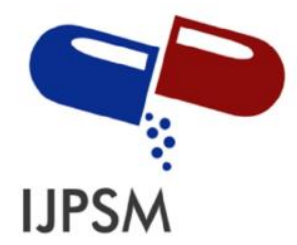

Engla Kartika et al, Int. Journal of Pharmaceutical Sciences and Medicine (IJPSM), Vol.6 Issue. 1, January- 2021, pg. 75-82

ISSN: 2519-9889

Impact Factor: 3.426

The antibacterial effectiveness of polyacetylene compounds (falcarinol, acetoxyfalcarinol, and panaxjapyne) and glucosinolate from carrot powder have been tested against strains Gram-positive, Gram-negative, and methicillin-resistant Staphylococcus aureus (MRSA). Gram-positive bacteria used are S. aureus, MRSA, and B. cereus, and Gram-negative bacteria used were E. coli and S. typhimurium. The results showed that the only polyacetylene compound falcarinol had antibacterial with an inhibitory concentration (MIC) for $S$. aureus= $46.9 \mu \mathrm{g} / \mathrm{mL}$, MRSA $=37.6 \mu \mathrm{g} / \mathrm{mL}$, B. cereus $=12.5 \mu \mathrm{g} / \mathrm{mL}$. While the glucosinolates (glucosinolate, glukonapine, phenethyl, progoitrin, and sinigrin) only showed an antibacterial effect against the Gram-positive S. aureus $(\mathrm{MIC})$ strain. $=46.9 \mu \mathrm{g} / \mathrm{mL})$, MRSA $(\mathrm{MIC}=46.9 \mu \mathrm{g} / \mathrm{mL})$, and B. cereus $(\mathrm{MIC}=62.5 \mu \mathrm{g} / \mathrm{mL})$. Falcarinol and sinigrin can function as sources of natural antibacterial agents for food products [21].

\subsection{Sedative Activity}

The ethanol extract of carrot tubers (Daucus carota L.) was tested for sedative activity using a dose of 140 $\mathrm{mg} / \mathrm{kg}, 280 \mathrm{mg} / \mathrm{kg}$, and $560 \mathrm{mg} / \mathrm{kg} \mathrm{BW}$, respectively. Negative control animals were given distilled water of 10 $\mathrm{mL} / \mathrm{kg} \mathrm{BW}$, and positive control animals were given $5 \mathrm{mg} / \mathrm{kg} \mathrm{BW}$ of diazepam. Based on the Two-way ANOVA test results and the Duncan test, the experimental results showed that the ethanol extract of carrot tubers had a sedative effect. The dose of $560 \mathrm{mg} / \mathrm{kg} \mathrm{BW}$ has the highest sedative effect. The higher the ethanol extract dose of carrot tubers (Daucus carota L.), the higher the impact of a strong sedative effect on the presence of flavonoid and saponin chemical compounds [22].

\subsection{Antidepressant Activity}

Evaluation of the antidepressant activity of the ethanol extract of Daucus carota (EEDC) was carried out on male Swiss albino rats using various test methods such as FST, TST, AIH, RIH, and HTPPH tests. The ethanol extract of carrots at doses of $200 \mathrm{mg} / \mathrm{kg}$ and $400 \mathrm{mg} / \mathrm{kg}$ showed a significant increase in the mice's motor activity, which increased depressed mood, thereby reducing the immobility time of rats in the FST and TST tests. In Apomorphine \& Reserpine induced hypothermia, EEDC did not show anything against hypothermia produced by Apomorphine and Reserpine. EEDC demonstrated significant potentiation of mouse heads in the 5-HTP assay. All tests show that the ethanolic extract of Daucus carota has antidepressant activity by inhibiting serotonin reuptake, which works through serotonergic receptors (G-protein coupled receptors) as mood elevators. Thus, it gives pharmacological credence to its traditional use in the treatment of depression [23].

\subsection{Anti-Cholesterol Activity}

The effectiveness of carrot stew has been tested on the reduction of cholesterol levels in hypercholesterolemic rats. The study results showed no difference in boiled carrots (Daucus carota $\mathrm{L}$.) on reducing blood cholesterol levels in white rats with a hyper cholesterol diet. The time of therapy is only three days and uses a low dose of $0.144 \mathrm{mg}$. The amount required is $10 \mathrm{mg}$ of the drug simvastatin to have a cholesterol-lowering effect in mice [24].

The effect of carrot extract (Daucus carota L.) has been tested on atherosclerosis in male quail by administering Prophylthiouracyl (PTU) and high-fat foods using three doses, namely $50 \mathrm{mg} / \mathrm{kg} \mathrm{BW,} 100$ $\mathrm{mg} / \mathrm{kg} \mathrm{BW}$, and $200 \mathrm{mg} / \mathrm{kg} \mathrm{BW}$. The extract doses of $100 \mathrm{mg} / \mathrm{kg} \mathrm{BW}$ and $200 \mathrm{mg} / \mathrm{kg} \mathrm{BW}$ could prevent the formation of atherosclerosis, which was characterized by aortic wall thickness, aortic lumen area, and endothelial cell damage, which were not different from negative controls $(\mathrm{P}<0.05)$. Meanwhile, the extract dose of $50 \mathrm{mg} / \mathrm{kg} \mathrm{BW}$ did not prevent the formation of atherosclerosis, which was characterized by aortic wall thickness, aortic lumen area, and endothelial damage, which were not different from the positive control (P> $0.05)$ [25].

The administration of tomato and carrot juice has been tested in minimizing hypercholesterolemia in the use of pharmacological therapy. Based on the One-Way ANOVA test, carrot and tomato juice treatment has a significant and practical effect in reducing blood cholesterol levels. The presence of pectin compounds evidences it. The pectin compound is useful for lowering cholesterol levels in the blood. The impact of intense juice giving is necessary to encourage family members to provide the fluid to rapidly help the oxidation 


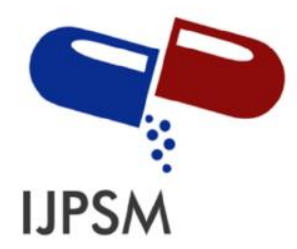

Engla Kartika et al, Int. Journal of Pharmaceutical Sciences and Medicine (IJPSM), Vol.6 Issue. 1, January- 2021, pg. 75-82

ISSN: 2519-9889

Impact Factor: 3.426

process from the accumulation of fat or plaque in the blood vessels to minimize the dependence effect of using pharmacological drugs [26].

\subsection{Anti-Gastric Ulcer Activity}

The effect of carrot extract on gastric ulcers has been tested in white male rats induced by $1 \mathrm{~mL} / 200 \mathrm{gram} \mathrm{BW}$ absolute ethanol given orally. Giving absolute ethanol can cause stomach ulcers. The results showed that carrot juice at a dose of $3 \mathrm{~mL} / \mathrm{kg} \mathrm{BW}, 6 \mathrm{~mL} / \mathrm{kg} \mathrm{BW}$, and $12 \mathrm{~mL} / \mathrm{kg} \mathrm{BW}$ restored gastric ulcers with healing percentages of $28.412 \%, 46.797 \%$, and $75.766 \%$, respectively [27]. Carrot leaf water extract was prepared by maceration and was administered at a dose of 50,100 , and $200 \mathrm{~mL} / \mathrm{kg}$ orally. The results showed that the water extract of Daucus carota leaves had a significant effect ( $p<0.05-0.001)$. It suggests that the leaves' aqueous extract has a cytoprotective effect and reduces secretory secretion, thereby protecting against gastric and duodenal ulcers [28].

\subsection{Anticancer Activity}

Carrot petroleum extract has been shown to have anticancer activity by fighting breast cancer cell lines. The carrot petroleum extract fraction has a significant anti-proliferative effect on human breast cancer cell lines MDA-MB-231 and MCF-7 showed dose cytotoxicity against both lines. Cell. Also, pentane (F1) and pentane/diethyl ether (F2) fractions showed higher anticancer activity than other fractions (F3, F4). Both F1 and F2 fractions inhibited cell proliferation by inducing cell cycle cessation and apoptosis in MDA-MB-231 cells. This apoptosis induction is done through inhibition of the ERK pathway. The results showed that carrots could be considered a potential source of natural anticancer compounds [29].

The anticancer activity of carrot extract against human colon and breast cancer cells (MCF-7, cancer cell line MDA-MB-231) was evaluated using the trypan blue exclusion method and the WST-1 cell proliferation assay. Carrots were extracted with a 50:50 acetone-methanol mixture. The extract was analyzed by gas-mass chromatography spectrometry. The results showed a significant increase in cell death and decreased cell proliferation, so that carrot extract has promising anticancer activity [13].

\subsection{Kidney Protective Activity}

Research on the effect of carrot infusion in preventing kidney cell disorders due to uranium exposure has been carried out with carrot infusion concentrations of 10,20, and 30\%. This study indicates that $30 \%$ carrot infusion can prevent kidney cell damage better than the $10 \%$ and $20 \%$ levels. Based on histopathological examination, it is proven that carrot infusion has protective power against renal cell necrosis due to nephrotoxic radioactive compounds [30].

\section{Conclusion}

Carrot plant (Daucus carota L.) is a plant that is rich in chemical compounds. These chemical compounds are distributed in every part of the plant, such as vitamins (A, B, C), alkaloids, carotenoids, flavonoids, tannins, anthraquinones, carbohydrates, saponins, diterpenes, steroids, phenolic acids, beta-carotene, phenols, coumarin, triterpenoids, essential oils, chlorogenic acid, folic acid, pantothenic acid. Also, carrots contain minerals (sodium, calcium, phosphorus, iron, potassium, sodium, magnesium, chromium) and other compounds that benefit from treating various diseases. Carrots have pharmacological activities: antioxidant, antibacterial, sedative action, anti-inflammatory, antifungal, anthelmintic, anticancer, antidepressant, anticholesterol, gastric anti-ulcer, and kidney protection activity. Carrots with the main content of beta carotene, an antioxidant, can protect from free radicals that damage body cells. 


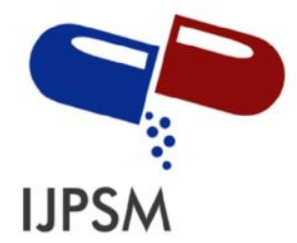

Engla Kartika et al, Int. Journal of Pharmaceutical Sciences and Medicine (IJPSM), Vol.6 Issue. 1, January- 2021, pg. 75-82

ISSN: 2519-9889

Impact Factor: 3.426

\section{References}

[1]. https://it.wikipedia.org/wiki/Daucus carota

[2]. https://id.wikipedia.org/wiki/Wortel

[3]. Lesmana M. Buku Pintar Pohon Wortel. Jakarta: Lembar Langit Indonesia; 2015: 9-18.

[4]. http://plantamor.com/species/info/daucus/carota

[5]. Dalimartha S. Atlas Tumbuhan Obat. Ed 2. PT. Pustaka Pembangunan Swadaya Nusantara: Trubus Agriwidya; 2000: 197-99.

[6]. Ayeni EA, Abubakar A, Ibrahim G, Atinga V, Muhammad Z. Phytochemical, nutraceutical and antioxidant studies of the aerial parts of Daucus carota L. (Apiaceae). Journal of Herbmed Pharmacology. 2018; 7 (2): 68-73

[7]. John S, Priyadarshini S, Monica SJ. Phytochemical profile and thin layer chromatographic studies of Daucus carota peel extracts. International Journal of Food Science and Nutrition. 2017; 2 (1): 23-6

[8]. Kulkarni CP. Phytochemical analysis and total phenol content in Daucus carota Linn. International Journal of advanced science and research. 2017 November; 2 (6): 74-6

[9]. Jabrane A, Jannet HB, Harzallah- Skhiri F, Missouri M, Casanova J, Mighri Z. Flower and root oils of the Tunisian Daucus carota L. ssp. maritimus (Apiaceae): Integrated Analyses by GC, GC/MS, 13C- NMR Spectroscopy, and in vitro Antibacterial Activity. International Journal of Food Science and Nutrition. 2009 Juni; 6 (6): $881-89$

[10]. Kouri A, Dob T, Belkebir A, Krimat S, Chelghoum C. Chemical composition and antioxidant activity of the essential oil and the methanol extract Algerian wild carrot Daucus carota L. ssp. carota. (L.) Thell. J. Mater. Environ. Sci. 2015; 6 (3): 784-791.

[11]. Bystrica J, Kavalcova P, Musilova J, Vollmannova A, Tomas TO, Lenkova M. Carrot (Daucus carota L. ssp. sativus (Hoffm.) Arcang.) as a source of antioxidants. Acta agriculturae Slovenica. 2015 Nov 26; 105 (2): $303-311$.

[12]. Agustina A, Hidayati N, Susanti P. Penetapan kadar $\beta$-Karoten pada wortel (Daucus Carota L.) mentah dan wortel rebus dengan spektrofotometri visibel. Jurnal Farmasi Sains dan Praktis. 2019 April; 5(1):7-13.

[13]. Ghozaly MR, Safitri EB. Uji aktivitas antioksidan ekstrak n-Heksan, etil asetat dan metanol dari varietas umbi wortel (Daucus Carota L.) dengan metode DPPH (1, 1-Difenil-2-Pikrilhidrazil). Sainstech Farma. 2016 juli ; 9 (2): $13-18$.

[14]. Shabby WN, El- Sibai M, Smith KB, Karam MC, Mroueh M, Daher CF. The antioxidant and anticancer effects of wild carrot oil extract. Phytotherapy Research. 2012 June 9.

[15]. Aulia Y, Safitri F, Fadilah R. Efek anti inflamasi ekstrak etanol wortel (Daucus carota L.) terhadap tikus strain wistar (Rattus Novergicus) yang diinjeksi karagenan. 2013 Desember; 9(2):65-69.

[16]. Patil MVK, Kandhare AD, Bhise SD. Anti-inflammatory effect of Daucus carota root on experimental colitis in rats. International journal of pharmacy and pharmaceutical science. 2012; 4 (1): 337-343.

[17]. Fhatnur STA, Suprobowati OD, Sasongkowati R. Perbedaan efek anthelmintik ekstrak etanol umbi wortel (Daucus carota L.) varietas lokal dan impor terhadap cacing Ascaris sum. 2018; 7 (1): 553-559.

[18]. Kalsum U. Uji aktivitas ekstrak etanol umbi wortel (Daucus carota L.) sebagai antifungi terhadap pertumbuhan Candida albicans. Warta Farmasi. 2019 Oktober 10; 8(2): 71-80.

[19]. Lina N, Sari EP, Aini I. Uji aktivitas antifungi air perasaan wortel (Daucus carota L.) terhadap pertumbuhan jamur Candida albicans secara in vitro. Jurnal Insan Cendekia. 2020 Maret; 7 (1): 40-44.

[20]. Sirait AY, Pelealu NC, Yamlean PV.Y. Uji daya antibakteri ekstrak etanol umbi wortel (Daucus Carota L.) terhadap staphylococcus aureus dan escherichia coli Secara in vitro. Pharmacon Jurnal Ilmiah Farmasi. 2016 November; 5(4): 145-154.

[21]. Hinds L, Kenny O, Hossain MB, Walsh D, Sheehy E, Evans P, Gaffney M, Rai DK. Evaluating the antibacterial properties of polyacetylene and glucosinolate compounds with further identification of their presence within various carrot (Daucus carota) and Broccoli (Brassica oleracea) cultivars using high-performance liquid chromatography with a diode array detector and ultra-performance liquid chromatography-tandem mass spectrometry analyses. Journal of agricultural and food chemistry. 2017 July 3.

[22]. Erjon, Ningsih PW, Rikamasari Y. Efek sedatif ekstrak etanol umbi wortel (Daucus carota L.) pada mencit putih jantan galur swiss-webster. Jurnal Ilmiah Bakti Farmasi. 2017; 2(2):17-26.

[23]. Babu PN, Nagaraju B, Yamini K, Dhananjaneyulu M, Venkateswarlu K, Mubina M. Evaluation of antidepressant activity of ethanolic extract of Dacus Carota in Mice. J. Pharm.Sci \& Res. 2014; 6 (2): 73-77.

[24]. Misnanto M, Nurmawati T. Efektifitas Rebusan wortel (Daucus Carota L.) terhadap penurunan kadar kolesterol darah pada tikus putih (Rattus Norvegicus). Jurnal Ners dan Kebidanan (Journal of Ners and Midwifery). 2016 Desember; 3(3):286-291.

[25]. Suhatri S, Amir H, Rizal Z. Pengaruh ekstrak wortel (Daucus carota Linn.) terhadap aterosklerosis pada burung puyuh jantan (Cortunic-cortunix japonica). Jurnal Farmasi Higea. 2014; 6 (2): 183-192. 


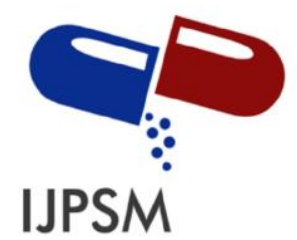

\section{Engla Kartika et al, Int. Journal of Pharmaceutical Sciences and Medicine (IJPSM), Vol.6 Issue. 1, January- 2021, pg. 75-82}

[26]. Vinorikanofia V, Ratnaindahsaridewi R. Pengaruh pemberian jus tomat dan wortel terhadap penurunan kadar kolestrol pada Pasien hiperkolesterolemia. Ensiklopedia of Journal. 2018 Oktober; 1(1):139-146.

[27]. Suhatri S, Rusdi R, Sugesti E. Pengaruh pemberian sari wortel (Daucus carota L.) terhadap tukak lambung pada tikus putih jantan. Jurnal Sains Farmasi \& Klinis. 2015 Nov 1; 2(1): 99-103.

[28]. Agbaje EO, Fageyinbo MS, Alabi OO. Gastro-duodenal protective effect of aqueous leaf extract of Daucus carota sartivus Linn. (Apiaceae) in rats and its possible mechanism of action. The Journal of Phytopharmacology. 2017; 6 (3): 156-163.

[29]. Shabby WN, Mroueh M, Bodman-Smith K, Mansour A, Taleb RI, Daher CF, El-Sibai M. Daucus carota pentanebased fractions arrest the cell cycle and increase apoptosis in MDA-MB-231 breast cancer cells. BMC complementary \& Alternative Medicine. 2014: 1-9.

[30]. Windhartono W, Kamal Z, Sasmito E. Pengaruh Infusa Wortel (Daucus carota L.) terhadap histopatologi ginjal tikus jantan yang diinduksi uranium. Jurnal Kedokteran Yarsi. 2013; 21 (1): 033-040.

\section{A Brief Author Biography}

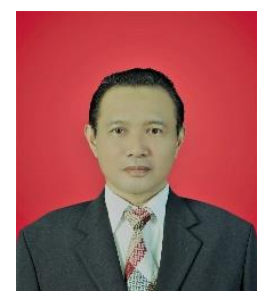

Prof. Dr. Harrizul Rivai, M.S., was born in Payakumbuh, West Sumatra, on 4 September 1953. His father is Rivai Said, and his mother is Saridahanum Syofyan. The Author obtained a Bachelor of Pharmacy from the Department of Pharmacy, Faculty of Mathematics and Natural Sciences, Padjajaran University, Bandung (1976), a Master of Science degree from the Bandung Institute of Technology (1984), and a Doctorate from the Department of Chemistry, Faculty of Mathematics and Natural Sciences, Andalas University, Padang (2011). Now the Author is a Professor and Researcher at the Faculty of Pharmacy, Andalas University, Padang. The Author also serves as Deputy Chair of Academic Affairs at the YPTIK Padang College of Pharmacy (STIFARM). The Author wrote the book "Principles of Chemical Examination" (Publisher UI-Press, 1995), translated the book "Pharmaceutical Statistics" (EGC Medical Book Publishers, 2010), and wrote "Chapter 4" in the book "Recent Research Advances in Biology Vol. 4 "(International Book Publisher, India, and United Kingdom, 2020). The Author has also written articles in various international journals in various science fields, such as chemistry, biology, and pharmacy. 